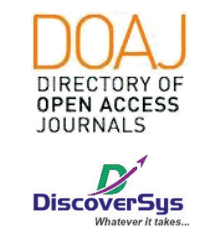

Published by DiscoverSys

\section{Karakteristik diare pada anak di RSUP Sanglah Denpasar tahun 2017}

\author{
I Dewa Made Satrianjaya, ${ }^{1 *}$ Ni Nyoman Metriani Nesa, ${ }^{2}$ Dewi Sutriani Mahalini ${ }^{2}$
}

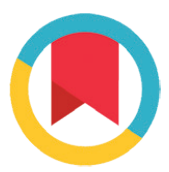

CrossMark

\title{
ABSTRACT
}

Background: Diarrhea is one of the most common diseases affecting children around the world. In Indonesia, the national rate of diarrhea prevalence is $9 \%$ where $16.7 \%$ of cases occur at 1-4 years old and $16.5 \%$ of cases at under one year old. In addition, dehydration causes most mortalities.

Aim: This study aims to determine the characteristics of diarrhea in children in Sanglah General Hospital, Denpasar.

Method: This study is a cross-sectional study design using secondary data from the register data in the Pediatric Division of Sanglah General Hospital Denpasar from January to November 2017. Of the 170 data, there were 165 survival samples. Characteristics of diarrhea in children are described using tables, pie charts, and graphs.
Result: Most of the sample were males (56.5\%), infants (40\%), patients from Denpasar (55.3\%) and those with good nutritional status (60\%). The mean age of the patient was 26.6 months, the mean body weight was $10.6 \mathrm{~kg}$, and the mean height was $79.8 \mathrm{~cm}$. Most of them were diagnosed with acute diarrhea (98\%), where the most common cause is a viral infection (75\%). The most common comorbid diseases are congenital heart disease and neurological disease (10.6\%). Most patients have only mild dehydration (57\%). Long term treatment of diarrhea patient in child wards mostly for 2-3 days.

Conclusion: Diarrhea in children in Sanglah Denpasar Hospital period January-November 2017 most suffered by men and babies, mostly from Denpasar. Most of them have acute diarrhea that is mainly caused by a viral infection.

Keywords: IgM IgG serology, thrombocyte, hematocrit, leucocytes

Cite the Article: Satrianjaya, I.D.M., Nesa, N.N.M., Mahalini, D.S. 2019. Karakteristik diare pada anak di RSUP Sanglah Denpasar tahun 2017. Intisari Sains Medis 10(2): 159-167. D0I: 10.15562/ism.v10i2.194

\section{ABSTRAK}

Diare adalah salah satu penyakit yang paling sering menyerang anak-anak di seluruh dunia. Di Indonesia, angka nasional prevalensi diare adalah $9 \%$ dimana $16,7 \%$ kasus terjadi pada usia 1-4 tahun dan 16,5\% kasus usia di bawah 1 tahun. Sebagian besar mortalitas disebabkan oleh dehidrasi. Tujuan: Untuk mengetahui karakteristik diare pada anak di RSUP Sanglah, Denpasar.

Metode: Rancangan penelitian cross-sectional, menggunakan data sekunder dari data register di bagian IImu Kesehatan Anak RSUP Sanglah Denpasar bulan Januari sampai November 2017. Dari 170 data, terdapat 165 sampel hidup dan 5 sampel meninggal dunia. Karakteristik diare pada anak digambarkan menggunakan tabel, diagram pie dan grafik.

Hasil: Sebagian besar sampel adalah laki-laki (56,5\%), bayi (40\%), pasien yang berasal dari Denpasar $(55,3 \%)$ dan yang memiliki status gizi baik (60\%). Rata-rata umur pasien adalah 26,6 bulan, berat badan rata-rata adalah $10,6 \mathrm{~kg}$ dan tinggi badan rata-rata $79,8 \mathrm{~cm}$. Sebagian besar didiagnosis dengan diare akut (98\%), dimana penyebab paling umum adalah infeksi virus (75\%). Penyakit penyerta paling umum adalah penyakit jantung kongenital dan penyakit saraf $(10,6 \%)$. Sebagian besar pasien hanya mengalami dehidrasi ringan (57\%). Lama perawatan penderita diare di bangsal anak sebagian besar selama 2-3 hari.

Simpulan: Diare pada anak di RSUP Sanglah Denpasar periode Januari-November 2017 paling banyak diderita laki-laki dan bayi, sebagian besar berasal dari Denpasar. Kebanyakan dari mereka mengalami diare akut yang sebagian besar disebabkan oleh infeksi virus.
Udayana

${ }^{2}$ Bagian/SMF IImu Kesehatan Anak Fakultas Kedokteran Universitas Udayana/Rumah Sakit Umum Pusat Sanglah

\section{*Correspondence to:}

I Dewa Made Satrianjaya, Program Studi Pendidikan Dokter, Fakultas Kedokteran, Universitas Udayana dewasatria327@gmail.com

Diterima: 04-04-2018

Disetujui: 18-07-2018

Diterbitkan: 01-08-2019
Kata kunci: serologi lgM lgG, trombosit, hematokrit, leukosit

Cite Pasal Ini: Satrianjaya, I.D.M., Nesa, N.N.M., Mahalini, D.S. 2019. Karakteristik diare pada anak di RSUP Sanglah Denpasar tahun 2017. Intisari Sains Medis 10(2): 159-167. DOI: 10.15562/ism.v10i2.194

\section{PENDAHULUAN}

Diare merupakan penyakit berbasis lingkungan dan terjadi hampir di setiap geografis dunia. Diare menjadi salah satu faktor penyebab utama kematian pada anak di negara berkembang. ${ }^{1}$ Diare pada anak sendiri didefinisikan sebagai meningkatnya volume feses harian melebihi batas atas yaitu $10 \mathrm{mg} / \mathrm{kgBB} /$ hari. $^{2}$ Diare merupakan penyakit kedua yang bertanggung jawab atas kematian 
578 ribu anak dengan umur dibawah 5 tahun pada tahun 2013, dan dari jumlah kematian tersebut, $26 \%$ persen diantaranya berasal dari daerah Asia Tenggara. ${ }^{3}$

Data WHO pada tahun 2013 menyatakan terdapat 1,7 miliar kasus diare di seluruh belahan dunia dengan 760 ribu kematian pada anak dibawah usia 5 tahun. ${ }^{4}$ Data dari Center of Disease Control and Prevention (CDC) mengungkapkan bahwa diare membunuh 2.195 anak setiap harinya dimana jumlah tersebut lebih besar dibandingkan dengan kematian akibat gabungan dari AIDS, malaria dan campak. Diare mengambil 11\% dari seluruh kematian pada anak. ${ }^{5}$ Data terbaru menyatakan bahwa terdapat sebanyak 2 miliar kasus diare di seluruh dunia yang terjadi setiap tahunnya, dimana 1,9 juta anak dibawah 5 tahun meninggal setiap tahunnya. Dari semua kematian tersebut, 78\% kematian terjadi di Asia dan Afrika. ${ }^{6,7}$

Di Indonesia, berdasarkan Riset Kesehatan Dasar pada tahun 2007, angka nasional prevalensi diare adalah $9 \%$, dimana $16,7 \%$ kasus terjadi pada anak berusia 1-4 tahun dan 16,5\% kasus terjadi pada anak dibawah usia 1 tahun. Pada tahun 2013, terjadi penurunan angka kasus diare dibandingkan pada tahun 2012 yaitu dari 1.654 kasus menjadi 646 kasus. ${ }^{8}$ Data terbaru dari Kementrian Kesehatan RI pada tahun 2015 menunjukkan bahwa pada tahun 2014 terjadi angka kejadian luar biasa pada kasus diare dimana kasus meningkat dari 646 kasus menjadi 2.549 kasus, tetapi pada tahun 2015 angka kejadian berhasil diturunkan kembali menjadi 1.213 kasus namun Case Fatality Rate tetap meningkat yaitu dari 1,14 menjadi 2,47. Angka kejadian diare di Provinsi Bali sendiri menduduki peringkat ke 17 dari 34 provinsi dimana kasus diare yang terjadi pada tahun 2015 adalah sebanyak 83.839 kasus sedangkan jumlah kasus diare yang ditangani di Provinsi Bali adalah sebesar 93.333 atau sekitar $111,3 \%$ kasus. $^{8}$

Sebesar $88 \%$ dari seluruh kasus diare disebabkan oleh air yang tidak layak minum, kurangnya sanitasi serta kurangnya hygiene pada masing-masing individu. Kebanyakan diare pada anak (40\%) berupa watery diarrhea yang disebabkan oleh infeksi dari rotavirus. Kasus diare ditransmisikan dari feses ke mulut (Fecal-oral) secara tidak langsung melalui konsumsi makanan dan minuman yang tercemar, kontak dari orang ke orang, serta adanya kontak langsung dengan material feses., ${ }^{2,5}$ Kontaminasi dari material feses dan rendahnya budaya mencuci tangan juga menyumbangkan 577 ribu kematian akibat diare. Sebesar 29,7\% kasus diare disebabkan oleh rendahnya akses sanitasi sedangkan 7,6\% kasus disebabkan oleh tidak adanya akses sanitasi. ${ }^{9}$ Beberapa hal lain juga diduga sebagai faktor resiko dari diare seperti usia anak, jenis kelamin anak, status gizi, penyakit penyerta serta faktor dari patogen penyebab diare itu sendiri. ${ }^{2}$ Pasien yang menderita diare biasanya mengeluhkan buang air besar yang lembek atau cair dengan frekuensi 3 kali atau lebih dalam waktu 24 jam. Terkadang, gejala bisa juga disertai dengan rasa tidak nyaman di perut (nyeri atau kembung), mual, dan muntah serta tenesmus. ${ }^{10}$

Kebanyakan orang menganggap penyakit diare sebagai penyakit yang wajar terjadi pada anak kecil. Banyak juga dari orangtua yang tidak menyadari faktor resiko dari diare pada anak serta tandatanda bahaya dari diare pada anak. Penyebab utama kematian pada kasus diare anak adalah terjadinya dehidrasi berat pada jenis watery diarrhea. ${ }^{1}$ Berdasarkan dari latar belakang ini, penulis merasakan adanya urgensi untuk mengangkat diare sebagai topik dari penelitian. Penelitian ini akan dilaksanakan dengan pengambilan data dengan menggunakan catatan data register pasien diare anak rawat inap di bagian pediatri RSUP Sanglah Denpasar, dimana rumah sakit tersebut bukan hanya menjadi rujukan utama pasien se-Bali akan tetapi menjadi rujukan utama se-Indonesia bagian Timur. Penelitian ini penting untuk dilakukan sebagai data dasar untuk mengenali karakteristik klinis dari diare anak, usaha untuk mencegah bertambahnya kasus diare pada anak serta sebagai bahan acuan untuk perencanaan penatalaksanaan diare anak khususnya di Bali.

\section{METODE}

Penelitian ini menggunakan rancangan deskriptif cross-sectional dimana peneliti akan melakukan pengumpulan data pada satu saat tertentu, bersifat non-eksperimental. Target populasi dalam penelitian ini adalah seluruh pasien diare anak di Bali. Populasi sampel yang digunakan adalah semua pasien diare anak di Bagian Ilmu Kesehatan Anak RSUP Sanglah Denpasar dari bulan Januari 2017 - November 2017. Sampel penelitian semua pasien anak diare di rawat di bangsal anak Bagian Ilmu Kesehatan Anak RSUP Sanglah Denpasar sebanyak 78 sampel. Pengambilan sampel dilakukan dengan menggunakan metode consecutive sampling, dimana subjek pada populasi sampel yang memenuhi kriteria inklusi dan eksklusi dimasukkan ke dalam penelitian.

\section{HASIL}

Terdapat 180 data register pasien diare anak yang dirawat inap yang terdaftar periode Januari 2017 November 2017. Dari 180 data tersebut, sebanyak 
Tabel 1 Tabel Sebaran Proporsi Data Sosiodemografi pada Kasus Diare Anak

\begin{tabular}{|c|c|c|}
\hline Karakteristik & Jumlah ( $N=170)$ & Persen (\%) \\
\hline \multicolumn{3}{|l|}{ Jenis Kelamin } \\
\hline Laki-Laki & 96 & 56,5 \\
\hline Perempuan & 74 & 43,5 \\
\hline \multicolumn{3}{|l|}{ Umur $(26.6 \pm 31.94)$} \\
\hline Infant & 68 & 40 \\
\hline Toodler & 61 & 35,88 \\
\hline Preschool & 18 & 10,59 \\
\hline Anak diatas 5 tahun & 23 & 13,53 \\
\hline \multicolumn{3}{|l|}{ Asal Pasien } \\
\hline Denpasar & 94 & 55,3 \\
\hline Badung & 18 & 10,6 \\
\hline Jimbaran & 4 & 2,3 \\
\hline Gianyar & 6 & 3,5 \\
\hline Bangli & 4 & 2,3 \\
\hline Tabanan & 10 & 5,9 \\
\hline Klungkung & 3 & 1,7 \\
\hline Karangasem & 5 & 2,9 \\
\hline Negara & 4 & 2,3 \\
\hline Singaraja & 6 & 3,5 \\
\hline Nusa Penida & 1 & 0,6 \\
\hline NTB & 8 & 4,7 \\
\hline NTT & 3 & 1,7 \\
\hline Lombok & 1 & 0,6 \\
\hline Pulau Jawa & 3 & 1,7 \\
\hline \multicolumn{3}{|l|}{ Status Gizi } \\
\hline Baik & 102 & 60 \\
\hline Kurang & 45 & 26,5 \\
\hline Buruk & 18 & 10,6 \\
\hline Lebih & 5 & 3 \\
\hline
\end{tabular}

Tabel 2 Distribusi Penyakit Penyerta yang Dimiliki Pasien Diare Pada Anak

\begin{tabular}{llc}
\hline Golongan Penyakit & Jenis Penyakit & Jumlah \\
\hline $\begin{array}{l}\text { Penyakit Jantung Bawaan } \\
(\mathbf{1 0 . 6 \% )}\end{array}$ & Defek Septum & 3 \\
& Atrial Septal Defect (ASD) & 7 \\
& Ventricular Septal Defect (VSD) & 3 \\
Tidak Tertutupnya struktur Embriologis Jantung & 3 \\
Patent Foramen Ovale (PFO) & 2 \\
Persistent Duktus Arteriousus (PDA) & 18 \\
Tetralogi of Fallot (TOF) & Total
\end{tabular}


Tabel 2 Continue

Golongan Penyakit

Jenis Penyakit

Jumlah

Keganasan

(5.3\%)

Keganasan Hematologi

Acute Mieloblastic Leukemia (AML)

1

Acute Lymphoblastic Leukemia (ALL)

1

Limphoma non Hodgkin (LNH)

Keganasan non Hematologi

Neuroblastoma

1

Retinoblastoma

2

Karsinoma Ginjal

Total

Kelainan Traktus Digestivus (4.2\%)

Kelainan Usus, Anus, Rektum

\begin{tabular}{|c|c|}
\hline$(4.2 \%)$ & Hernia Umbilikalis \\
\hline & Gastroschisis \\
\hline & Hischprung \\
\hline & Malformasi Anorektal \\
\hline & Kelainan Gizi dan Metabolisme \\
\hline & Marasmus \\
\hline & Hipertiroid \\
\hline & Hipotiroid \\
\hline & DM Tipe 1 \\
\hline & Total \\
\hline Kelainan Neurologi & Cerebral Palsi \\
\hline & Edema Cerebri \\
\hline & Sindrom Ekstrapiramidal \\
\hline & Ensepalopati metabolik \\
\hline & Hidrochepalus \\
\hline & Epilepsi \\
\hline & Nistagnus Kongenital \\
\hline & Total \\
\hline Infeksi & HIV \\
\hline (8.2\%) & Infeksi CitoMegalo Virus \\
\hline & Infeksi Telinga Akut \\
\hline & Infeksi TB Spine \\
\hline & Total \\
\hline Kelainan Pernapasan & Bronkiolitis \\
\hline$(3.5 \%)$ & Bronkodisplasia Pulmonal \\
\hline & Pneumonia \\
\hline & Total \\
\hline Lain Lain & Anemia Defisiensi Besi \\
\hline$(9.4 \%)$ & Thalasemia \\
\hline & Crest Sindrom \\
\hline & Down Sindrom \\
\hline & Obesitas \\
\hline & Puberti Prekok \\
\hline & Reye Sindrom \\
\hline & Total \\
\hline
\end{tabular}




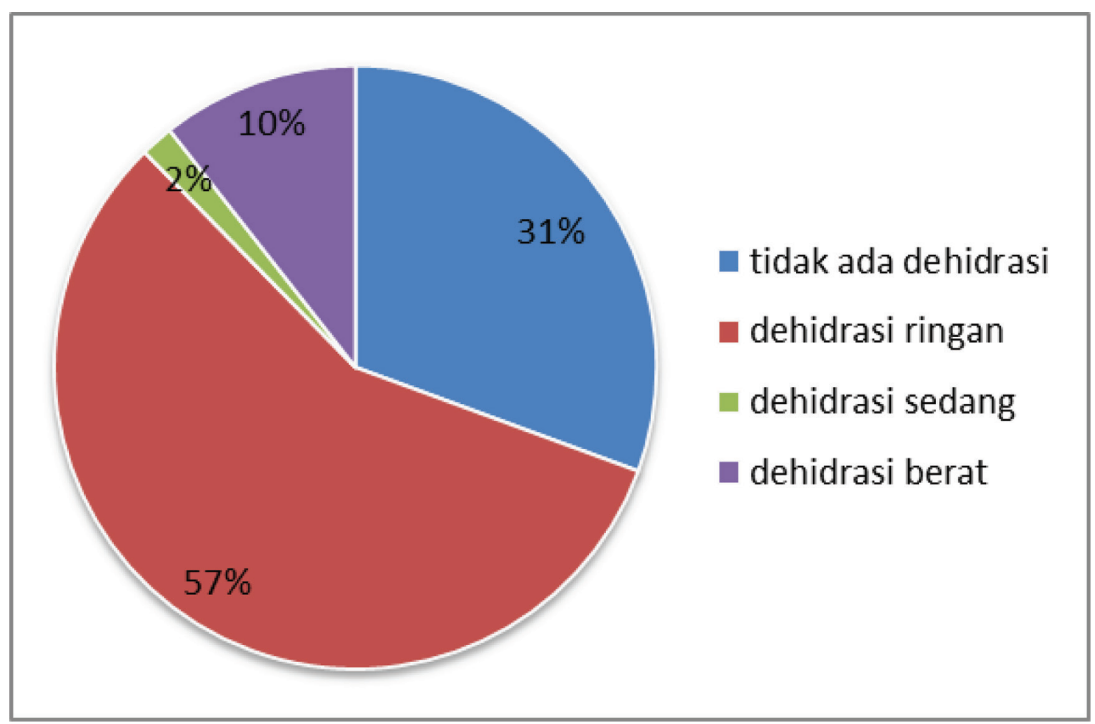

Gambar 1 Distribusi Proporsi Penderita Diare Anak Berdasarkan Derajat Dehidrasi

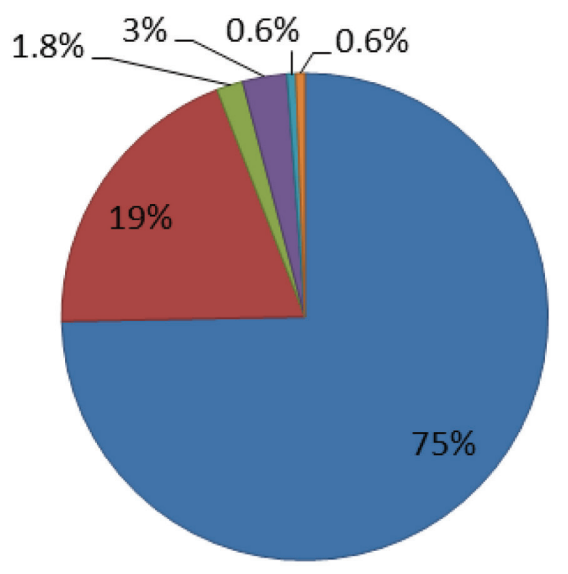

Virus

Bakteri

Laktosa Intoleran'

Jamur

Intoksikasi Obat

Malabsorbsi Lemak

Gambar 2 Distribusi Proporsi Penderita Diare Anak Berdasarkan Penyebab Diare

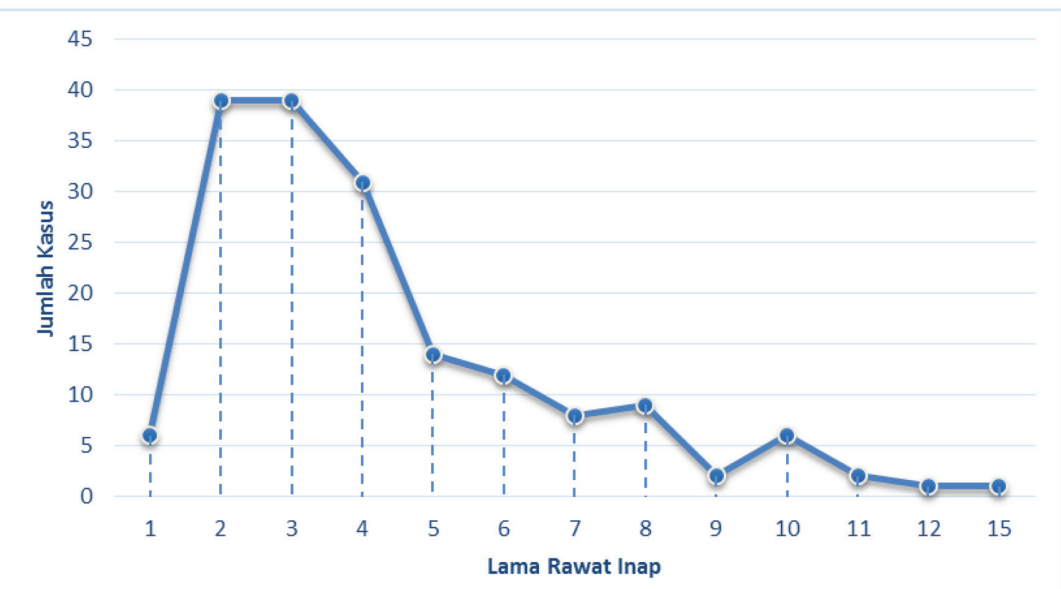

Gambar 3 Distribusi Proporsi Lama Rawat Inap (hari) Pada Kasus Diare Anak

10 data register tidak memiliki variabel yang dicari, sehingga terdapat 170 data register diare pada anak yang bisa diteliti pada periode tersebut. Sejumlah 165 pasien $(97,1 \%)$ pulang dengan kondisi membaik, sementara 5 pasien $(2,9 \%)$ meninggal dalam perawatan.

\section{Distribusi Proporsi Data Sosiodemografi pada Kasus Diare Anak}

Pada Tabel 1 menggambarkan karakteristik pasien diare anak yang berdasarkan ciri sosiodemografi. Rata-rata usia sampel tergolong remaja mendekati dewasa, yaitu 26.6 bulan. Sejumlah 68 orang (40\%) pasien diare anak merupakan pasien berusia 1-12 bulan. Bila ditinjau dari jenis kelamin, pasien lakilaki lebih banyak mengalami diare anak (56,5\%) dibandingkan perempuan (43,5\%). Kebanyakan pasien berasal dari Denpasar $(55,3 \%)$ dan terdapat pasien yang berasal dari luar Pulau Bali (8,8\%) dengan rincian Nusa Tenggara (6,5\%), Lombok $(0,6 \%)$ dan Pulau Jawa (1,7\%). Berdasarkan status gizi mayoritas pasien memiliki status gizi yang baik (60\%), pasien dengan status gizi yang kurang sebanyak 26,5\%, status gizi buruk $10,6 \%$ dan pasien dengan status gizi yang lebih sebanyak $3 \%$. Hasil penelitian menunjukkan berat badan minimal anak pada kasus diare adalah $3 \mathrm{~kg}$ dan maksimal $44 \mathrm{~kg}$ dengan rata-rata berat badan 10,6 kg. Sedangkan panjang badan minimal adalah $58 \mathrm{~cm}$ dan maksimal $146 \mathrm{~cm}$ dengan rata-rata panjang badan $79,8 \mathrm{~cm}$.

\section{Distribusi Proporsi Penderita Diare anak Berdasarkan Diagnosis Utama, Penyebab Diare, dan Status Dehidrasi}

Berdasarkan diagnosis utama, mayoritas pasien didiagnosis dengan diare akut (98\%) sedangkan 2\% sisanya didiagnosis dengan diare kronis. Gambar 1 menggambarkan distribusi proporsi penderita diare anak berdasarkan status dehidrasinya. Kebanyakan pasien diare anak mengalami dehidrasi ringan (57\%), disusul dengan pasien tanpa dehidrasi (31\%), dan pasien dengan dehidrasi sedang (10\%). Hanya sebagian kecil pasien yang mengalami diare dengan dehidrasi berat (2\%).

Gambar 2 menggambarkan distribusi proporsi penderita diare anak berdasarkan penyebab terjadinya diare. Kebanyakan pasien mengalami diare disebabkan oleh infeksi virus (75\%), sedangkan infeksi bakteri memberikan kontribusi sebesar 19\% dari kasus diare pada anak. Penyebab diare lainnya yang ditemukan adalah infeksi jamur $3 \%$. Selain patogen, diare pada anak juga dapat disebabkan oleh penyebab non infeksi diantaranya adalah akibat laktosa intoleran $(1,8 \%)$, intoksikasi obat $(0,6 \%)$ serta gangguan absorbsi lemak $(0,6 \%)$. 


\section{Distribusi Proporsi Penderita Diare Berdasarkan Penyakit Penyerta}

Hasil penelitian menunjukkan sebagian besar, yaitu sejumlah 95 (55.9\%) anak yang mengalami diare yang dirawat di RSUP Sanglah memiliki penyakit penyerta selain diare anak. Dari semua penyakit penyerta selain diare anak, sebagian besar (10.6\%) berasal dari penyakit jantung bawaan dan penyakit kelainan neurologis. Dari lingkup penyakit jantung bawaan, defek pada septum atrium dan ventrikel merupakan kelainan yang terbanyak ditemukan. Sedangkan pada ruang lingkup neurologis, didominasi oleh penyakit ensepalopati metabolik dan epilepsi. Penyakit infeksi selain penyebab diare juga menyertai terjadinya diare misalnya infeksi HIV yang terjadi pada 11 pasien diare anak di RSUP Sanglah. Kelainan lain yang juga menyertai diare pada anak adalah kelainan dalam sistem pencernaan, kelainan dalam sistem pernapasan, dan kelainan lainnya yang didominasi dengan obesitas pada anak (6 pasien).

\section{Distribusi Proporsi Lama Perawatan Serta Hasil Perawatan pada Kasus Diare Anak}

Seluruh pasien dalam penelitian ini merupakan pasien diare anak yang menjalani rawat inap di RSUP Sanglah. Lama perawatan minimal adalah 1 hari sedangkan maksimal 15 hari. Sebagian besar pasien $(23 \%)$ menjalani rawat inap sebanyak 2 hari dan 3 hari. Sedangkan hanya $0.6 \%$ dari total pasien yang menjalani perawatan hingga 12 dan 15 hari.

Berdasarkan hasil perawatan, mayoritas pasien dapat pulang kerumah dengan keadaan membaik setelah menerima perawatan di RSUP Sanglah (97\%). Namun sebanyak 3\% pasien ( $\mathrm{n}=5$ anak) meninggal selama menjalani perawatan di RSUP Sanglah.

\section{DISKUSI}

\section{Distribusi Proporsi Data SosioDemografi pada Kasus Diare Anak}

Pada Tabel 1 dapat dilihat bahwa penderita diare anak paling banyak pada penelitian ini adalah laki-laki yaitu 96 pasien (56.5\%). Hal ini sesuai dengan hasil temuan dari studi yang meneliti profil diare dari seluruh negara, dimana dikatakan bahwa laki-laki memiliki kesempatan 9\% lebih besar dibandingkan perempuan untuk menderita diare. Hasil temuan di Indonesia juga mengambarkan hal serupa dimana pada penelitian di RSUD Tanjung Balai Karimun, ditemukan penderita laki-laki merupakan $52.5 \%$ dari total penderita dan penelitian di Padang juga menunjukkan jumlah penderita laki-laki yang lebih banyak daripada perempuan yaitu 75.9\%. Penelitian di provinsi yang sama juga menunjukkan hasil serupa, dimana pada penelitian yang dilakukan di Tabanan, Bali pada 3 tahun sebelumnya didapatkan penderita diare dengan jenis kelamin laki-laki berjumlah lebih banyak dibandingkan dengan perempuan $(56.44 \%$ vs $43.56 \%) .{ }^{11}$ Meskipun hasil epidemiologi yang ditemukan selalu konsisten, namun hingga kini belum diketahui alasan dibalik lebih tingginya angka kejadian diare pada anak laki-laki dibandingkan anak perempuan.

Penelitian ini menunjukkan bahwa pasien paling banyak berasal dari kelompok umur 6-11 bulan (25.9\%) dimana jika dikelompokkan menjadi kelompok lebih besar, maka pasien didominasi oleh kelompok umur di bawah 24 bulan (62.35\%). Data studi dari Hung dkk pada tahun 2006 juga menunjang dari hasil penelitian ini dimana mereka menyatakan bahwa prevalensi diare lebih tinggi pada kelompok anak yang lebih kecil dengan prevalensi terbanyak ada pada kelompok umur 1-12 bulan. $^{2}$ Semakin muda pasien maka akan semakin mudah pasien untuk terkena diare. Setiap pertambahan umur 1 bulan maka kesempatan anak untuk menderita diare akan berkurang $2 \%$. Pernyataan ini juga sesuai dengan hasil analisa menurut SKDI 1995 dimana umur balita 12-24 bulan memiliki risiko 2.23 lebih besar untuk menderita diare. Penelitian di Tabanan pada tahun 2013 menunjukkan bahwa penderita terbanyak berasal dari kelompok umur di bawah 24 bulan ( 2 tahun) dibandingkan dengan kelompok umur $25-59$ bulan $(67.8 \%$ vs $32.20 \%) .{ }^{11}$ Hasil epidemiologi yang konsisten dengan kelompok umur diduga disebabkan karena pada anak yang berusia di bawah 2 tahun, kekebalan alaminya belum terbentuk sehinga akan rentan dalam mengalami infeksi.

Pasien mayoritas berasal dari Denpasar (55.3\%) disusul oleh Badung (10.6\%), dan Tabanan (10\%) sisanya berasal dari wilayah lain. Dari segi lokasi, hasil temuan ini sedikit berbeda dengan hasil penelitian sebelumnya dimana daerah dengan tingkat pendapatan lebih kecil akan memiliki jumlah penderita diare lebih banyak dikarenakan daerah tersebut memiliki hubungan dengan penduduk yang kurang sejahtera dengan higienitas dan status nutrisi yang buruk. Meskipun ketiga daerah yang disebutkan merupakan daerah dengan pendapatan yang tinggi, hal ini kemungkinan terjadi karena lokasi RSUP Sanglah yang terletak di Denpasar dan hanya berjarak masing-masing sebesar $14 \mathrm{~km}$ dan $23 \mathrm{~km}$ terhadap Badung dan Tabanan. Selain itu, jumlah penduduk di Denpasar juga lebih besar dibandingkan kabupaten lainnya sehingga memungkinkan jumlah pasien yang juga lebih banyak. Selain itu, status RSUP Sanglah yang merupakan RS rujukan tersier menyebabkan pasien yang berasal dari luar denpasar hanya merupakan pasien dengan kondisi tertentu yang tidak mampu di tangani oleh RSUD di daerah masing-masing. 
Berdasarkan status gizi yang di lihat pada tabel 1, mayoritas pasien memiliki status gizi yang baik (60\%), pasien dengan status gizi yang kurang sebanyak $26.5 \%$, status gizi buruk $10.6 \%$ dan pasien dengan status gizi yang lebih sebanyak $3 \%$. Hal ini sesuai dengan hasil penelitian yang dilakukan oleh Iskandar dkk dimana ditunjukkan bahwa $85.8 \%$ pasien diare memiliki status gizi yang baik. Namun mereka menemukan bahwa status gizi yang buruk berkaitan dengan lebih lamanya waktu rawat inap, keparahan diare serta lamanya diare dibandingkan dengan penderita diare dengan status gizi yang baik. Selain itu, pasien dengan status gizi yang buruk cenderung memiliki penyakit penyerta yang memperberat kondisi diare. ${ }^{12}$

\section{Distribusi Proporsi Penderita Diare anak Berdasarkan Diagnosis Utama, Penyebab Diare, dan Status Dehidrasi}

Berdasarkan hasil distribusi proporsi diare dapat dilihat bahwa penderita diare anak paling banyak di diagnosis dengan diare akut (98\%) dengan penyebab terbanyak adalah virus (75\%). Diare akut sendiri merupakan diare dengan onset yang mendadak $(<72$ jam) berlangsung kurang dari 2 minggu dengan penyebab tersering adalah infeksi virus diantaranya adalah rotavirus. ${ }^{2} \mathrm{Hal}$ ini serupa dengan penelitian yang dilakukan di daerah Serpong, Jawa Barat dimana pasien mayoritas mengalami diare akut (94.1\%) dibandingkan dengan diare persisten. ${ }^{13}$ Penyebab diare tersering dalam penelitian ini adalah virus (75\%). Hal ini sesuai dengan penelitian dari China yang menemukan bahwa rotavirus (54\%), dan norovirus (9.2\%) merupakan penyebab tersering dari diare pada anak. ${ }^{14}$ Rotavirus dikatakan sebagai penyebab diare utama pada anak terutama di negara berkembang. Hal ini disebabkan karena sebagian besar negara berkembang belum mendistribusikan vaksin rotavirus secara merata. Selain itu, rotavirus dikatakan menyebar lebih mudah daripada bakteri dikarenakan karakteristiknya sebagai virus yang lebih tahan dari berbagai kondisi dibandingkan dengan bakteri. ${ }^{15}$ Pada penelitian ini, tidak dapat diketahui jenis virus secara spesifik dikarenakan keterbatasan penelitian ini yang hanya mencari data dari data register. Selain itu, pemeriksaan jenis virus dengan menggunakan PCR kurang memungkinkan untuk dilakukan di RSUP Sanglah dikarenakan keterbatasan biaya dari masing-masing pasien.

Pada penelitian ini, ditemukan jumlah pasien yang mengalami dehidrasi adalah $69 \%$ dari total pasien sedangkan $31 \%$ pasien tidak mengalami dehidrasi. Jenis dehidrasi yang mendominasi adalah dehidrasi ringan (57\%). Hal ini bersesuaian dengan literatur yang tersedia sebelumnya, dimana pasien dengan diare dewasa ini lebih sering nampak dengan derajat dehidrasi ringan. Hal ini dikaitkan dengan sudah tingginya tingkat pengetahuan ibu mengenai diare dan dampaknya yang berupa dehidrasi, sehingga pasien datang sebagian besar dengan keadaan sudah terehidrasi dari rumah. Pasien dengan dehidrasi berat umumnya terjadi pada pasien dengan diare yang disebabkan oleh virus dan parasit. Dehidrasi berat merupakan salah satu penyebab kematian dari kasus diare pada anak. ${ }^{15}$ Dehidrasi berat juga biasanya terdapat pada pasien dengan kondisi malnutrisi sebelum diare. ${ }^{16}$

\section{Distribusi Proporsi Penderita Diare Berdasarkan Penyakit Penyerta}

Penyakit penyerta terbanyak yang terdapat dalam penelitian ini adalah penyakit jantung bawaan dan kelainan neurologi (masing-masing 10.6\%). Keberadaan penyakit penyerta ini disebabkan karena RSUP Sanglah merupakan rumah sakit rujukan tersier dimana anak dengan diare yang datang kebanyakan (55.9\%) tidak hanya menderita diare namun memiliki penyakit pemberat lain yang menyebabkan fasilitas kesehatan tingkat pertama tidak mampu menangani anak tersebut. Anak dengan penyakit jantung bawaan yang menyebabkan gagal jantung dikatakan memiliki risiko diare yang lebih tinggi. Hal ini dikaitkan dengan penggunaan diuretik yang dapat menurunkan tingkat serum zinc yang berpengaruh terhadap perkembangan sistem pencernaan sehingga anak lebih rentan untuk menderita diare. ${ }^{17}$ Selain itu anak dengan PJB juga cenderung memiliki status nutrisi yang buruk yang juga dapat menurunkan fungsi sistem imunitas sehingga memudahkan anak untuk terserang infeksi termasuk infeksi saluran cerna. ${ }^{18}$ Sedangkan pada anak dengan kelainan penyerta pada sistem neurologi memiliki risiko lebih tinggi untuk terkena diare dikarenakan tingkat higienitas yang lebih rendah dibandingkan anak normal. Hal ini diakibatkan karena kesulitan dalam melakukan aktivitas sehari-hari. Kelainan yang melibatkan sistem saraf juga diduga berpengaruh terhadap gerakan usus pada anak. Literatur mengatakan bahwa pada beberapa kelainan neurologi, gerakan usus menjadi lebih lambat sehingga rentan untuk mengalami infeksi. Selain itu terdapat juga hubungan pada anak dengan gangguan sistem saraf dan otak dengan malnutrisi dimana hal ini secara tidak langsung akan mempengaruhi kejadian diare pada anak tersebut.

Setelah PJB dan kelainan neurologi, Infeksi merupakan penyerta kedua terbanyak pada pasien diare anak di RSUP Sanglah dengan dominasi infeksi HIV. Infeksi HIV dapat menurunkan sistem imunitas anak secara signifikan sehingga anak akan lebih rentan terhadap infeksi patogen yang menyebabkan diare. Pada anak dengan HIV, diare lebih sering disebabkan oleh jamur maupun flora normal 
usus yang pada umumnya tidak menyebabkan diare pada anak tanpa HIV. Kondisi HIV pada anak diare juga mempengaruhi tingkat keparahan, lama rawat inap dan juga lamanya durasi diare pada anak. ${ }^{4}$

\section{Distribusi Proporsi Lama Perawatan Serta Hasil Perawatan pada Kasus Diare Anak}

Hasil pada penelitian ini menunjukkan bahwa mayoritas pasien dapat pulang kerumah dengan keadaan membaik setelah menerima perawatan di RSUP Sanglah (97\%). Namun sebanyak 3\% pasien $(\mathrm{n}=5$ anak) meninggal selama menjalani perawatan di RSUP Sanglah. Rata-rata lama rawat inap pada pasien diare anak adalah 2-3 hari dengan minimal rawat 1 hari sedangkan maksimal 15 hari. Sebagian besar pasien (23\%) menjalani rawat inap sebanyak 2 hari dan 3 hari. Sedangkan hanya $0.6 \%$ dari total pasien yang menjalani perawatan hingga 12 dan 15 hari. Kematian pada pasien diare memiliki korelasi sedang dengan status gizi dan korelasi rendah dengan penyakit penyerta. Sedangkan status dehidrasi dan penyebab diare tidak memiliki korelasi yang signifikan secara statistik dengan mortalitas pada pasien diare anak.

Kondisi malnutrisi dikatakan dapat mempengaruhi keparahan diare serta derajat dehidrasi pada pasien diare anak. Pasien dengan malnutrisi dikaitkan dengan asal mereka yang berasal dari lingkungan dengan higienitas rendah sehingga transmisi dari patogen lebih cepat terjadi serta patogen yang menginfeksi umumnya lebih ganas dibandingkan dengan pasien dari lingkungan dengan higineitas tinggi. ${ }^{16}$ Penyakit penyerta ini memiliki korelasi lemah yang signifikan terhadap mortalitas diare. Penyakit penyerta terbanyak pada penelitian ini adalah PJB dan kelainan neurologis. Dikatakan bahwa penyakit penyerta pada kondisi diare anak dapat meningkatkan keparahan penyakit dan lama rawat inap pada pasien. Rawat inap dengan periode yang lebih lama juga memberikan kontribusi terhadap terjadinya infeksi nosocomial yang dapat memperburuk kondisi diare anak. Status nutrisi yang juga rendah pada anak dengan penyakit penyerta turut memberikan peran dalam meningkatkan mortalitas pada kasus diare anak..$^{17,18}$ Status dehidrasi dan penyebab diare pada penelitian ini ditemukan tidak signifikan secara statistik. Hal ini berbeda dengan penelitian yang ada sebelumnya dimana dikatakan bahwa diare yang disebabkan oleh virus memiliki tingkat mortalitas yang lebih tinggi dikarenakan kecenderungan diare yang disebabkan oleh virus untuk menimbulkan derajat dehidrasi yang berat. Derajat dehidrasi berat dikatakan meningkatkan mortalitas pada pasien diare dikarenakan kondisi hipovolemik dan ketidakseimbangan elektrolit yang dapat berakibat fatal bagi pasien. ${ }^{15,19}$

\section{SIMPULAN}

Dari segi sosiodemografik, rata-rata usia penderita diare anak yaitu 26.6 bulan dengan proporsi penderita terbanyak yaitu kelompok usia 1-12 bulan (40\%), jenis kelamin terbanyak yaitu laki-laki (56.5\%), asal terbanyak dari Denpasar (55.3\%), dan status gizi secara mayoritas baik (60\%). Rata-rata berat badan anak adalah $10 \mathrm{~kg}$ dengan minimal $3 \mathrm{~kg}$ dan maksimal $44 \mathrm{~kg}$. Sedangkan rata-rata tinggi badan anak adalah $79.8 \mathrm{~cm}$ dengan tinggi maksimal $146 \mathrm{~cm}$ dan minimal $58 \mathrm{~cm}$.

Diagnosis terbanyak adalah diare akut (98\%), kebanyakan mengalami dehidrasi ringan (57\%), dan sebagian besar diare yang dialami anak disebabkan oleh infeksi virus (75\%). Sebagian besar pasien memiliki penyakit penyerta lain disamping diagnosis diarenya (55.9\%). Penyakit penyerta yang mendominasi pada kasus diare anak ini adalah PJB dan kelainan neurologis (masing-masing 10.6\%). Sebagian besar pasien di rawat dalam waktu 2 hari dan 3 hari (masing-masing 23\%). Sebanyak 3\% pasien meninggal selama menjalani perawatan.

\section{KETERBATASAN PENELITIAN}

Masalah rekam medis yang banyak tidak tersedia saat pencarian dapat memengaruhi hasil penelitian secara signifikan. Maka dari itu, perlu ada penanganan masalah lebih lanjut mengenai manajemen penataan dan penyimpanan rekam medis agar tidak terjadi hal yang serupa kedepannya.

\section{DAFTAR PUSTAKA}

1. Aung Tin, McFarland Willi, Khin Hnin, dkk. 2013. Incidence of Pediatric Diarrhea and Public-Private Preferences for Treatment in Rural Myanmar: a Randomized Cluster Survey. Journal of Tropical Pediatrics;59(1):p.10-16

2. Hung Bui. 2006. The Most Common Cause of Risk Factor for Diarrhea among Children Less Than Five Years of Age Admitted to Dong Anh Hospital, Hanoi, Northern Vietnam. University of Oslo

3. Azage Muluken, Kumie Abera, Worku Alemayehu. 2016. Childhood Diarrhea in High and Low Hotspot District of Amhara Region, Northwest Ethiopia: A Multilevel Modeling. Journal of Health, Population and Nutrition;35(13):p.1-14

4. Farthing Michael, Salam Mohammed, Lindberg Greger, dkk. 2013. WHO Guideline : Acute Diarrhea in Adults and Childern. World Health Organization

5. Center of Disease Control and Prevention. 2015. Diarrhea: Common Illness, Global Killer. US Departement of Health and Human Sevices

6. World Health Organization. 2015. Birth Defects Surveillance Training Facilitator's Guide.WHO Libarary Catalouging in Publication Data

7. Vajinath Santhosini, Sangeetha S, Prakash R, dkk. 2016. Rotaviral Diarrhea in Childern Less than 5 Years with Reference to Their Vaccination Status in a Tertiary Care Hospital. International Journal of Current Microbiology and Applied Science;5(3):p.206-211

8. Kementrian Kesehatan RI. 2015. Profil Kesehatan Indonesia Tahun 2015. Kemenkes RI 
9. Crocker Jonny, Bartram Jamie. 2016. Intepreting the Global Enteric Multicenter Study Findings on Sanitation, Hygiene and Diarrhea. Plos Medicine

10. Ikatan Dokter Indonesia. 2015. Pedoman Praktik Klinis Untuk Faslitas Layanan Kesehatan. Kementrian Kesehatan Republik Indonesia

11. Darmika Aditya, Somia Agus. 2016. Karatkeristik Penderita Diare Pada Anak Balita di Kecamatan Tabanan Tahun 2013. E Jurnal Medika; 5(11)

12. Iskandar Wiliam, Sukardi Wayan, Soenarti Yati. 2015. Risk of Nutritional Status on Diarrhea Among Under Five Children. Pediatricia Indonesiana; 55(4):235-238

13. Handayani Putri. 2013. Gambaran Karateristik Kejadian Diare pada Balita di Klinik Wijaya Kusuma Serpong. Repositori UPH

14. Yu Zin, Cheng Wei-Xia, Yang Xue-Mei, dkk. 2008. Viral Agent Associated with Acute Gastroenteritis in Childern Hospitalized with Diarrhea in Lanzou China. Journal of Clinical Virology

15. Ahmed Makhdum, Abedin Jaynal, Alam Faisal, dkk. 2017. Incidence of Acute Diarrhea Associated Death Among Children $<5$ Years of Age in Bangladesh, 2010-2012. Am J of Trop Med Hyg
16. Ferdous Farzana, Das Sumon, Ahmed Shwanaz dkk. 2013. Severitu of Diarrhea and Malnutrition Among Under Five Year Old Childern In Rural Bangladesh. Am J Trop Med Hyg; 89(2):223-228

17. Sadoh WE, Sadoh AE. 2013. Serum Zinc Values in Children with Congenital Heart Disease. African Health Science; 13(3): 601-606

18. Indra Rafner, Cristina Tobing, Siregar Ahmad, dkk. 2017. Nutritional Status in Childern With Congenital Heart Disease : Prevalence and Its Associated Factors. Repositori USU

19. Omore Richard, Jacquelline E, Ciara E, dkk. 2016. Epidemiology, Seasonality and Factors Associated with Rotavirus Infection Among Children with Moderate to Severe Diarrhea in Rural Western Kenya, 2008-2012: The Global Enteric Multicenter Study. Journal Poen

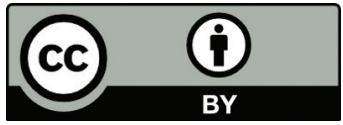

This work is licensed under a Creative Commons Attribution 